\title{
Fiscal Decentralization in the Czech and Slovak Republics: A Comparative Study of Moral Hazard
}

Phillip J. Bryson

phil_bryson@byu.edu

Gary C. Cornia

Gloria E. Wheeler

Follow this and additional works at: https://scholarsarchive.byu.edu/facpub

Part of the Economics Commons

\section{Original Publication Citation}

Phillip J. Bryson, Gary C. Cornia and Gloria E. Wheeler, "'Fiscal Decentralization in the Czech and Slovak Republics: A Comparative Study of Moral Hazard,"' Environment and Planning C:

Government and Policy 24, Vol. 22, NO. 1, February, pp. 13-113.

\section{BYU ScholarsArchive Citation}

Bryson, Phillip J.; Cornia, Gary C.; and Wheeler, Gloria E., "Fiscal Decentralization in the Czech and Slovak Republics: A Comparative Study of Moral Hazard" (2004). Faculty Publications. 456.

https://scholarsarchive.byu.edu/facpub/456 


\title{
Fiscal Decentralization in the Czech and Slovak Republics:
} A Comparative Study of Moral Hazard

Phillip J. Bryson*

\author{
Gary C. Cornia**
}

And

Gloria E. Wheeler*

\author{
*Brigham Young University \\ **Brigham Young University \\ and \\ Lincoln Institute of Land Policy
}

Short Lead: Moral Hazard: Czech/Slovak Property Tax

Contact Information

gary@lincolninst.edu or 617.661.3016 


\begin{abstract}
Fiscal decentralization has provided neither the benefits of decentralization nor an independent revenue source for subnational governments in the Czech and Slovak Republics. In Slovakia, political conditions early in the transition led to the relative neglect of revenue transfers from the center. This produced financial stress but also encouraged greater fiscal independence for local governments. It also forced them to seek maximal property tax revenues. The Czech Republic made more substantial transfers to local governments, but the development of fiscal autonomy was stifled as transfers reduced the need for own-source local revenues. The Czech real estate tax has remained nominal as it was under central planning, and its administration is fraught with moral hazard problems. Thus, the property tax never became a vehicle for generating independent funds but the prospects for the tax are much brighter in the Slovak Republic. This article offers several views on why the property tax has been more successful in the Slovak Republic.
\end{abstract}




\section{Fiscal Decentralization in the Czech and Slovak Republics: A Comparative Study of Moral Hazard}

\section{Introduction}

Since the economic transition began in Europe over a decade ago, fiscal decentralization has been viewed in the transition literature as essential to democratic development. It is one of the primary means of ensuring the efficiency of public services as government is brought closer to the people (Tanzi, 1991; Litvack, Ahmad, and Bird, 1998). Decentralization elicits heavy support from the public finance, public choice, and public management literatures (Tiebout, 1956; Bish and Kirk, 1974) because it makes public decision making more transparent and accountable; it also permits citizens to participate effectively and at low cost (Oates, 1998).1 Unfortunately there are gaps between the theoretical literature and the outcomes of decentralization. For example, local governments in transition countries have often been overburdened with unfunded mandates and woefully inadequate funds (Bahl and Wallace, 1994).

Examples of confident steps toward decentralization do exist. Following the velvet revolution the decentralization of local governments in the Czech and Slovak Republics was bold. There was a substantial increase in the number of local governments in both Republics and today there are 6,234 in the Czech region and 2,781 in Slovakia. The two Republics have more local governments per 10,000 citizens than their regional neighbors: roughly twice as many as Hungary and five or six times as many

1 There are also questions raised about decentralization. For example, there is a fear that decentralization creates a political process that leads to the under-provision of public goods by local

governments anxious to spare their own budgets rather than let spending benefits spill over beyond 
as Bulgaria, Albania, Russia, Ukraine, Romania or Poland.

But successful decentralization requires more than just forming local governments; it also requires that subnational governments have access to funding for basic services and even to a local and autonomous source of funding (Kelly, 1994). The public finance literature suggests that the property tax embodies the positive characteristics required of a local tax because its base is immobile, its revenue is stable, economically it is potentially neutral, and politically it is visible (Musgrave, 1983 and Oates, 1996). The tax assignment literature accepts the property tax as the ideal local tax (McClure, 1983). We see the development of a successful property tax as a critical step in government building. We agree with Bahl (2002) that when the property tax is not implemented, successful decentralization may be undermined and potential welfare gains lost (Bahl 2002).

Unfortunately, administrative and practical problems complicate the use of the property tax (Bahl and Linn, 1992) and suggest that it will remain critically under-used (Dunn and Wetzel, 2000)2. For example, if there is not a functioning real estate market, how do you establish a property's market value (Bertaud and Bertrand, 1994)? The property tax also presents political problems. Because taxes were basically invisible under central planning, public officials have no doubt that citizens will resent the imposition of this direct and visible tax. Both citizens and public officials appear more comfortable with indirect taxes such as the VAT (Youngman and Malme, 1994) and are inclined to resort to excise taxes and fees (Schleifer and Vishny, 1998).

In this article we review data that illuminate important differences in the administration of the property tax in the transitioning Czech and Slovak republics. Our thesis is that divergent revenue

local borders.

2 There is also evidence that the property tax can be underused in developed countries like the United States (Hovey, 1995). 
yields reflect varying degrees of collection effort. The difference is striking and has important ramifications for the development of local fiscal autonomy in the two republics. In the Czech Republic the property tax becomes relatively less important over time, while it grows in importance in Slovakia.

These diverging trends are significant because even after ten years of separation the two countries share virtually identical property tax laws. The shared history of these two republics extends back to the early twentieth century and shares a forty-year period of unified government and fiscal institutions under socialism. After the Velvet Revolution of 1989 and before the "Velvet Divorce" of 1993 they jointly reformed their fiscal system, adopting a standard European tax system. The fiscal system was in place when the two republics were formed and, as noted, with respect to the property tax continues to share identical rates and valuation methods. The latter were based not on the market value of property or improvements, but on the use of the property, the size $\left(\mathrm{M}^{2}\right)$ of the plot and buildings, and (in the case of agricultural parcels) the productivity of the land (Bryson and Cornia, 2001a and 2001b).3 Thus, differences in the relative importance of the property tax in either country cannot be attributed to either changes in the value base or the rates. 4

3 Local governments can modify the amount of property tax imposed by multiplying the taxes due by a pre-determined coefficient. In both republics the size of the coefficient is established by the center and local governments have generally opted to multiply by the highest possible coefficient.

4 Local governments in both republics can make adjustments to the property tax obligation. Such adjustments can be based on the use of property (i.e. environmental or investment) or on the economic status of the occupants (e.g., as pensioners of a given age and income level). The definitions on the adjustments are essentially identical for both republics. 
Why, then, are there divergent rates of growth in Czech and Slovak property tax revenues? As noted above we suggest the divergent property tax revenue yields can be attributed to the effort of property tax collection; the Slovak Republic more consistently identifies and taxes existing parcels. We believe it safe to assume, along with Bird and Slack (1991), Hubbard, Giovannini, Slemrod (1993), and Shah (1994), that regardless of good policy design administrative design and effort are critically important factors in determining tax yields. In Dillinger's (1991) view the difference may be attributed to the attention paid to the "sharp end" of property tax collection.

Having begun with this brief review of the benefits of decentralization and the need for an independent revenue source for the achievement of self-government, this article will proceed as follows. Section II will address the level of government responsible for property tax policy and administration. This is done from the perspective of principal/agent relationships, taking into consideration the moral hazard problems such relationships may imply for property tax systems. In the context of both the national and local budgets of the twin republics, municipal revenues derived from the property tax and other fiscal transfers are addressed in Section III. Discussion and conclusions are offered in the final section IV.

\section{Tax Policy, Tax Administration, and Moral Hazard}

We turn now to a consideration of the appropriate degree of centralization for the critical elements of taxation policy, both its design and administration. Public officials determine what level of government will design the tax policy, what level will administer it, what level will collect the revenues, and the level that will receive and use such revenues. Naturally, the same level of government can set the policy, administrate the tax, and receive the revenues. In the case of the US we observe a federally designed and administered personal income tax. Within the individual states, property tax policy is established by the state government and administered by special service local governments. Most of 
the revenue accrues to school districts, although they have no policy or administrative role in property taxation. In Taiwan, the VAT is largely administered at the provincial level, but overall policies governing its use are set by the national government, and the revenue is split between the central and provincial governments.

In the case of the property tax, there are strong arguments for assigning most of the policy and administrative activities to the central government. In both transitional and developing countries, this will make available more abundant fiscal and personnel resources, including more administrative and technical expertise from national and international consultants, access to more sophisticated information technology systems, and an overall harmonization of tax policies (World Bank, 1996). Safeguards for harmonization and uniformity must be established for every tax, but the need for such safeguards is especially strong with respect to the property tax. For most other taxes the taxable value or tax base is established in arm's length market transactions. But this is not how the property process functions, especially in transition countries. Because property is sold or exchanged infrequently, it is not common to find an individual parcel of property with a recently verified, marketdetermined value. Thus, the property tax requires that a tax administrator estimate a market and a taxable value for each parcel of property and its related improvements. Unfortunately, political access, ethnic or religious background, or even corruption can influence this process of value estimation.

There is a potential for a race to the bottom in terms of the kinds of property included in the tax base; there may likewise be a race to undervalue some properties. Local governments pursuing private rather than public interests may ignore certain properties while including others, or they may tax some properties heavily and reduce the tax burden on others. Such behavior may have serious implications for revenue yields, not to mention those for equity and stability. Centralization may avoid some of this behavior by protecting local administrators from the political opposition that can 
accompany the property tax (Bird, 1993). Centralized policy guidelines that set high standards for equity and administrative performance could avert many potential abuses, so the case for centralized policy design is a legitimate one. Although Breton (1996) does not specifically discuss the property tax his general arguments suggest that it should be administered at the central level of government.

Before turning to the benefits accruing to decentralization, let us consider the advantages that accrue to centralized administration of some of the specific functions of the property tax. In small transition countries, property valuation will probably best be performed by experts at the center. It is unlikely that either the federal or municipal levels will have an adequate number of valuation experts, but simple valuation techniques can minimize the problem. Central officials will probably be preferable, being less easily influenced by pressures emanating from within municipalities to keep estimated values low.

Central tax administration will enjoy better technical support, information technologies, GIS, mapping, cadastral support, and modeling techniques. It will also have access to international expertise. Other resource issues will also favor central involvement, i.e., financial resources and the assistance of supranational agencies. To the extent that scale and scope economies may exist in tax administration, the central government will be in the better position to exploit them. The center will also be less likely to be influenced by political pressures when appeals are made.

At the central level, the decisions that are made regarding policy reflect more appropriate safeguards to assure property tax uniformity both between and within taxing jurisdictions. Reasonable centralized policies accommodate the required degree of administrative transparency, indicate the types of property to include in the tax base, determine the actual tax rate, the valuations methodologies, the level and frequency of property assessments, and the uses of the funds (Kelly, 2000). However, there are also significant administrative advantages to decentralization, especially 
regarding the discovery and valuation of property. Property valuation may be accomplished more accurately at the local level, since local appraisers would have a better appreciation of local market nuances.5 Regardless of the sophistication or technologies employed in appraisal, the accuracy of the process will probably improve if appraisers review results and make subjective modifications according to their specialized skills. Discovery of property parcels and audit of tax records are also advantageously performed at the local level. Both processes benefit from the incentives of local appraisers to exert effort to maximize the coverage of taxable properties. Thus, while a process of local administration is expected to fall short in a variety of administrative and technical areas, it does have the advantage that the actors involved are informed about local economic, political, and fiscal conditions and preferences (Dillinger, 1992).

It must be observed here that in the Czech and Slovak republics valuation expertise is not the critical issue in improving property tax assessment. Since the property tax assessed value is based exclusively on the use of the property, the square meters of a structure or the hectares of a parcel, the key issue is finding property and properly measuring its size. In this case, the use of local experts is based almost exclusively on their knowledge of the location and size of the properties.

\section{Moral Hazard}

Although considerations presented in the previous section seem to smile on the centralization of property tax policy and administration, the incentive incompatibilities associated with such centralization must be considered. The case for decentralization is best understood in terms of principal-agent conflicts. Arguments for centralization assume that there are no substantial differences

5 In a property tax system where the value of the tax base is determined by the capitalized value of the property or the sales price of the property, it stands to reason that the more knowledge a person has about the local real estate market, the more accurate the appraisal. 
in the incentives of the central and sub-national governments. Unfortunately, moral hazard problems do arise in this area because agents pursue interests other than those of the principal.

In the case of property tax administration, who is the agent and who is the principal? In this context we follow Breton (1996) and consider the local government the principal and the central government the agent.6 We do this because the local government is closer to the citizens and is their proxy when the central government is engaged to pursue the fiscal interests of the people through the property tax.7 Variations on these assumptions have been used fruitfully in the literature. Bale and Dale (1998) and Moe (1990) describe principal-agent relationships, for example, between senior bureaucrats and subordinate bureaucrats, but also between citizens, politicians, and governmental levels.

When the property tax is centrally administered, the principal (local government) receives tax

6 We recognize that the principle/agent model is simplified as applied here; we exclude the role of property owners, citizens, and those who benefit from the public expenditures. But the crux of the fiscal situation is in fact captured in an analysis of the interplay between central and local government, where the latter is seen as the representative closest to the citizen and makes a good proxy for the citizen in matters of locally delivered public services. In a democracy, the citizen is, of course, the principal, but modeling the situation as we do highlights the core issues and significant relationships.

In a federal system, the local government will have trouble monitoring the agent central government, which is problematic because of their conflicting goals. Agents are not always unfettered in their behavior. In some instances, national and sub-national governments will monitor each other to the extent possible, with both levels attempting to promote the interests of the principal, the citizen. 7 Of course, local governments can also pursue the interests of elected officials rather than those of the public at large and also produce moral hazard problems in their role as agent of the electorate. 
revenue as a result of the agent's actions in tax collection, but the agent central government receives none of the revenues (other than a possible administration or collection fee) for its efforts. In the Czech case, where the Ministry of Finance has the assignment of policy design and administration, there is no collection fee. We posit that the agent's or central government's actions and effort have strong implications for revenue yields. In Figure 1 the relationship is shown between property tax revenues, PTR, and effort, $q$, where the former is a function of the latter. For simplicity, one may regard $q$ as a proxy for the variety of resources available to central governments for tax and other administrative functions. These resources include scarce manpower, computer and information systems, and even political capital. But the focus here is on the administrative effort that is so important for an effective tax.

Subnational governments in this model would hope that maximal effort, shown as $q^{*}$ in Figure 1, would be supplied by the central government. The preferences of the principals (the citizens or their local government) are for large receipts from central collections. But they have no clear sense

\section{Figure 1 here}

of the revenue frontier $(\mathrm{O}-\mathrm{N})$ and they are not in a position to monitor closely the effort or the effectiveness of the use of available resources in the central agent's tax administration. The principal does not have sufficient information to know that the agent is functioning at point $q^{1}$ rather than at $q^{*}$, the point at which revenues have reached a maximum and cannot be increased by further effort. The point $q^{*}$ is the point at which the full legal tax has been collected for every parcel of taxable real estate. At point $q^{1}$, the yield is less than it could be $(B$ rather than $A)$ if the center applied the necessary effort. This realistically describes the situation in the Czech Republic. Local governments do not share property tax data and are not in a position to monitor the central government's tax collection activities. 
The agent has its own utility function, the arguments of which are both property tax revenue and $q$--or better, leisure, the lack of $q$. (This contrasts with the preference function of the principal, the only argument of which is revenue.) The indifference curve $(U)$ represents the center's preferences for trading off property tax revenue and effort. The center willingly gives up revenues $A B$ for more discretion in the use of $q$. The fact that the principal will receive less property tax revenue may encourage the agent to offer greater revenue transfers from other taxes or revenue sources that don't require as much effort and don't involve as much potential political opposition. If so, the local governments are financially no worse off. But a pressing concern with the source of revenues available to the local governments and regions, is whether such funds come with strings attached. In the case of the Czech Republic, we have seen that this is the case.

Figure 1 represents what we believe to be happening in the Czech Republic. In the Slovak Republic, the more relevant utility functions are those of the municipalities and their incentive would be to move towards maximum property tax revenues. The coffers of the Slovak municipalities enjoy the benefits of the locals collecting their own property tax.

A brief description of the administrative processes in both republics should help to clarify our assumptions with respect to moral hazard. As noted, both countries have identical (area-based) valuation laws and tax rates. They both use self-reported returns supplied by the property owners (Bryson and Cornia, 2001a and 2001b), which presents the obvious need for discovery and audit. It is in these two functions where moral hazard problems are most likely. In the Czech Republic the Ministry of Finance receives the property tax returns, enters the data in an electronic inventory system and remits to local governments the property tax revenue based on the situs of the property owner. No efforts are made to find under-reported values or non-reported parcels.

In contrast, self-reported returns in Slovakia are submitted to local finance departments, which 
attempt to verify (audit) reported data and also match reported data with other records (discovery). In both countries the existing cadastral records were dated and inaccurate following the socialist period, so discovery and audit would naturally require more effort. In the larger cities of Slovakia, i.e., Bratislava and KoÓce, local finance offices are further decentralized into municipal districts with substantial fiscal and (with independently elected public officials) political autonomy, thus enhancing the decentralization effort. 8

Table 1 shows the implications of the degree of centralization of the design of tax policy on the one hand and administration and collection of the property tax on the other. The potential for moral hazard problems is also shown to be related to the degree of centralization. Clearly there is a role for central government, especially in the development of policy guidelines. Nevertheless, centralization of administration creates the potential for incentive incompatibilities and the eventual failure of the property tax. Even attractive, smart policy and administrative design cannot assure that a tax will succeed in the face of inept incentives (Tanzi, 1991).

\section{Table 1 here}

\section{Fiscal Transfers}

Moral hazard problems may also be involved when the central government transfers revenue to local governments (Bahl, 1999). This is especially likely if the redistribution process provides central funds that merely offset revenues the municipalities could reasonably have raised locally.9 Essentially,

8 It is not the focus of this paper, but an interesting question is whether the numerous small local governments in the Slovak Republic are counterproductive in terms of administrative ability and financial resources with respect to the collection of fees and taxes. In our view they are unlikely to prove to be efficient because of their size.

9 Fiscal redistribution is acceptable when (a) the distribution of local resources is badly skewed, and 
the central government offers compensation to the municipality for the property tax or other revenue it has failed to collect. When such transfers occur, the municipalities abdicate fiscal power to the central government; they relinquish self-determination for the convenience of revenue provision. Here, the local government is acting as an agent of local citizens and must share responsibility for the revenues foregone, as well as for the loss of local independence as central influence on local service provision will usually be attached to transfers of alternative funds. The consequence of these actions is that the importance and effect of the property tax are diminished, as is the potential for local fiscal autonomy. Of course, it is clear that local governments are often content with fiscal transfers because they avoid the political problems associated with raising own source taxes (Pisauro, 2001).

We turn now to the key question: which government, Czech or Slovak, has been most successful in terms of local finance, and why? As we have noted, the Slovak Republic has administered its property tax locally; the Czech Republic has administered it centrally. The Czechs have transferred considerable revenue to the local governments, while the Slovaks have been far less generous in providing transfers. The Czech Republic, having chosen a centralized approach to property tax administration, transfers substantial amounts of funds from the national to the local governments, but the Slovaks do not.

\section{Financing Municipalities}

Table 2 reports the financial situations in the two Republics from 1993 through 2001. It clearly shows the differences in the two countries' financial situations both at the national and municipal government levels. While both economies were growing throughout the period, the Czech economy has been considerably larger than Slovakia's. This is especially true when the exchange rate between

(b) when fiscal subsidies promote local activities particularly valued by the center (Musgrave, 1961). 
the two currencies is considered. From the beginning of the separation of the two countries the Slovak Crown has been about 30 percent less than the Czech Crown.

Table 2 here

The budgets of the two national governments grew during the period, but at a slower rate than the economies as a whole. In particular, note in Table 2 that the national budget as a proportion of the gross domestic product shrank in Slovakia from about 58 percent in 1993 to about 34 percent in 2001. The national budget of the Czech Republic began at around 35 percent, and over the period often went slightly below that share, but it ended at about the same share as Slovakia's.

The Local Revenues column of Table 2 show that Slovakia's municipalities were substantially poorer than those of the Czech Republic, with the Czech Republic's local revenues being from three to five times greater than Slovakia's. In terms of population the Czech Republic is almost exactly double the Slovak Republic. One reason for the differing local revenues is the divergent levels of national revenue sharing in the two countries. The central government provided a major portion of the local revenue in the Czech Republic, close to 30 per cent every year, while Slovakia's central government provided only between 7 and 17 per cent of the total local government revenue. (See the columns National Revenue Sharing and Rev Sharing/Local Revenues in Table 2).

Clearly, Slovak municipalities have had to search for other revenue sources to finance local service provision. Because Slovakia has chosen to administer, collect, and use property tax at the local level rather than centrally, the municipalities have the incentive and have developed the ability to find property and collect the tax. Notice in Table 2, although total local revenue in Slovakia is only about one-fifth as large as that of the Czech Republic, the amount of property tax revenue is almost equal throughout the periods examined. Table 2 shows that as a proportion of total local revenues, the Slovak Republic has been collecting an increasingly greater proportion of its total revenues from 
property tax, starting at about 12 percent in 1993 and increasing to 16 percent in 2001. During the same period, in the Czech Republic the proportion has dropped from three per cent to two per cent.

It is readily apparent that budget transfers from the center give the Czech Republic's local governments considerably greater revenue, and thus more flexibility than is the case for Slovakia. It may be a little less obvious that, because so much of Czech municipal funding comes from the state, there is much less budget autonomy. Oliveria and Martinez-Vazquez (2001) report that the funds that do come from the center to the local governments in the Czech Republic come with strings attached. Although some Czech taxes are earmarked for local use and there is latitude in local budgets, grants from the state budget are all tied to specific, state-approved projects.

By contrast, although national independence resulted in the impoverishment of Slovak municipalities and very hard budget constraints for them, independence also brought a large measure of budget autonomy from the center. By forcing Slovak municipalities to be more responsible for their own revenues, the Slovak Republic made it essential for the municipalities to increase the property tax yield, which should be a primary source of public revenues in any case.

In contrast, the Czech Republic has been noticeably lax in promoting the property tax as a source of independent revenues. Generous provision of fiscal transfers to Czech municipalities has obviated the need to develop the property tax as a more independent revenue source.

\section{Conclusions}

Consider a basic point of public finance in these neighboring republics. Moral hazard problems exist as a legacy of former planning systems and as a natural result of the institutional arrangements associated especially with the Czech property tax. These problems are present because the center is unwilling to inaugurate daring change in the provision of public services. Aspects of the former system 
retain strong appeal to policy agents in these countries. They would very much like to continue to retain some of the features of the central planning system. This would permit them to keep taxes indirect and non-transparent, so public services could be provided without political opposition. Such services would be financed by transfers (citizens under this tradition are disinclined to pay for services received) and the state would retain complete control over the programs funded.

In the transition, eastern Europeans were asked not only to accept a new philosophy and a new combination of social mechanisms for public goods provision, but also to give up the system they knew, along with the public and private goods provided by state-owned enterprises. Several kinds of public and even quasi-private goods were provided directly to the workers through state-owned enterprises--source of much of the housing, health care, nursery care, vocational training, general education, recreation, and even sports and vacation facilities for workers.

Perhaps supplying private citizens with acceptable public services in the municipalities can be postponed almost indefinitely, but it is not clear how countries that are extremely anxious to be associated with the European Union can indefinitely ignore public demands for acceptable provision. The transition to democracy, market economics, and self-determination at the local governmental level suggests that the question of municipal finance must ultimately be addressed in a more satisfactory manner.

Finally, the Slovak Republic is on a long-run path that will lead to stronger local government because those units have access to an autonomous revenue source and responsibility for their own fiscal situation. Although the Czech Republic has been more generous with its local governments and may for the foreseeable future have relatively more affluent local governments than in Slovakia, those subnational government units will not be as strong in terms of the political independence they enjoy. Generalizing from the Czech and Slovak experiences, the assignment of responsibilities for the 
property tax to the local level does in fact lead to a stronger, more independent fiscal system.

Naturally, in a system with so many small local governments, the resources are not always present to collect property tax or to provide a complete menu of public services. But the local governments are beginning to find ways to cope with their diminutive numbers and resources through alliances, for example, with other small local governments or even larger municipalities nearby. Since the will for independence is exceptionally strong, we believe ways will be found to enable the independent functioning of even the under-funded, small municipalities of Slovakia. 


\section{References}

Bale M and Dale J, 1992, Public Sector Reform in New Zealand and it Relevance to Developing Countries, The World Bank Observer, 13 (1) pp103-121.

Bahl R, Linn J, 1992, Urban Public Finance in Developing Countries, (New York: Oxford University Press).

Bahl, R, 1999, "Implementation Rules for Fiscal Decentralization," (International Studies Program, Working Paper, WP 99-1, Georgia State University, Atlanta, GA).

Bahl R, 2002, "Fiscal Decentralization, Revenue Assignment and the Case for the Property Tax," in Property Taxes in South Africa; Challenges in the Post-Apartheid Era, Eds M Bell, J Bowman (Lincoln Institute of Land Policy, Cambridge MA) pp 23-41.

Bahl R, Wallace S, 1994, "Revenue Sharing in Russia," Environment and Planning C: Government and Policy, 12, 293-307

Bertaud A, Renaud B, 1994, Cities Without Land Markets. (Washington, D.C.: World Bank) 
Bird R, Slack E, 1991, "Financing Local Governments in OECD Countries: the Role of Local Taxes and User Charges," in Local Government: an International Perspective. Eds J Owens and G Panella, eds., (Amsterdam: North-Holland) pp 83-97

Bird R, 1996, “Threading the Fiscal Labyrinth: Some Issues in Fiscal Decentralization,” National Tax Journal, 46 (2) pp 215-216

Bish R, Kirk R, 1974, Economic Principles and Urban Economics. (Englewood Cliffs, NJ, Prentice-Hall, Inc)

Breton A, 1996, Competitive Governments: An Economic Theory of Politics and Public Finance. (Cambridge University Press: Cambridge)

Bryson P, Cornia C, 2001a, "Taxes on Real Property in the Czech Republic," The Development of Property Taxation in Economies in Transition: Case Studies from Central and Eastern Europe (Washington, D.C.: The World Bank) pp. 39-50.

Bryson P, Cornia G, 2001b, "Land and Building Taxes in the Republic of Slovakia," The Development of Property Taxation in Economies in Transition: Case Studies from Central and Eastern Europe, (Washington, D.C.: The World Bank) pp. 51-66

Dillinger W, 1991, Urban Property Tax Reform: Guidelines and Recommendations, Urban Management and Municipal Finance. (Washington, D.C., World Bank).

Dillinger W, 1992, "Urban Property Taxation in Developing Countries," Background paper for World Development Report 1988. (Washington D.C.: World Bank)

Dunn J, Wetzel D, 2000, Fiscal Decentralization in Former Socialist Economies: Progress and Prospects. (Washington, D.C.: World Bank).

Hovey H, May, 1996, "The Property Tax in the 21 st Century," The Finance Project: Working Paper Series, Washington, D.C.

Hubbard, R, Giovannini A, Selmrod J, Eds. 1993, Studies in International Taxation (Chicago: University of Chicago Press)

Kelly R, 1994, "Implementing property-tax reform in transitional countries: the experience of Albania and Poland" Environment and Planning C: Government and Policy, 12, 319-331.

Kelly R, 2000, "Designing A Property tax Reform Strategy for Sub-Saharan Africa: An Analytical Framework Applied to Kenya, Public Budgeting and Finance, 20(3) pp. 36-51

Litvak J, Bird R, Ahmad J, 1998, Rethinking Decentralization in Developing Countries (Washington, D.C.: World Bank) 
McClure C, 1983, Tax Assignment in Federalist Countries. (Canberra: Centre for Research on Federal Financial Relations, Australian National University).

Moe T, 1990, Political Institutions: The Neglected Side of the Story, Journal of Law, Economics, and Organizations, 6(1) pp 213-253.

Musgrave R, 1961, “Approaches to a Fiscal Theory of Political Federalism,” in Public Finance: Needs Sources and Utilization. (National Bureau of Economic Research, New York, and Princeton: Princeton University Press) pp. 97-122

Musgrave R, 1993, "Who Should Tax, Where, and What?”, in McLure C, Jr., Ed. Tax Assignment in Federal Countries. (Canberra: Centre for Research on Federal Financial Relations, Australian National University) pp. 2-19

Oates W, 1996, "Taxation in a Federal System: The Tax-Assignment Problem," Public Economics Review 1(1) 35-60

Oliveira J, Martinez-Vazquez J, 2001, Czech Republic: Intergovernmental Fiscal Relations in the Transition,(The World Bank, Washington, D.C.).

Pisauro G, 2001, "Intergovernmental Relations and Fiscal Discipline: Between Commons and Soft Budget Constraints." (IMF Working Paper, WP/01/65, International Monetary Fund, Washington, D.C.).

Shah A, 1994, The Reform of Intergovernmental Fiscal Relations in Developing and Emerging Market Economies. (The World Bank, Washington, D.C.)

Shleifer A, Vishny R, 1998, The Grabbing Hand: Government Pathologies and Their Cures. (Cambridge Massachusetts: Harvard University Press)

Tanzi V, 1991, Public Finance in Developing Countries. (Edward Elger Publishing Limited, Aldershot, England)

Tiebout C, 1956, “A Pure Theory of Local Expenditures” Journal of Political Economy 54(5) 416-424

Youngman J, Malme J, 1994, An International Survey of Taxes on Land and Buildings (Kluwer Law and Taxation Publishers)

World Bank, 1996, From Plan to Market: World Development Report (Oxford University Press, Oxford) 
Figure 1

Property Tax Revenue and Administrative Effort

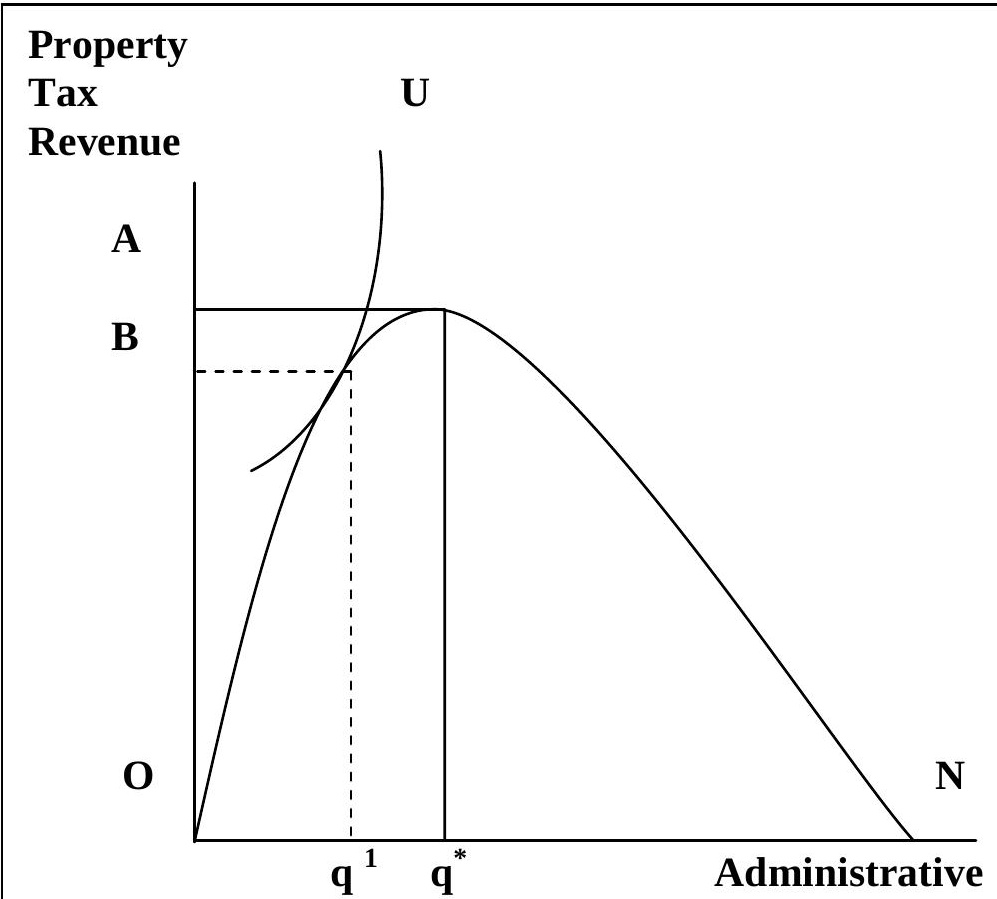




\section{Property Tax Policy Design}

Table 1

Moral Hazard: Property Tax Policy and Administration

Property Tax

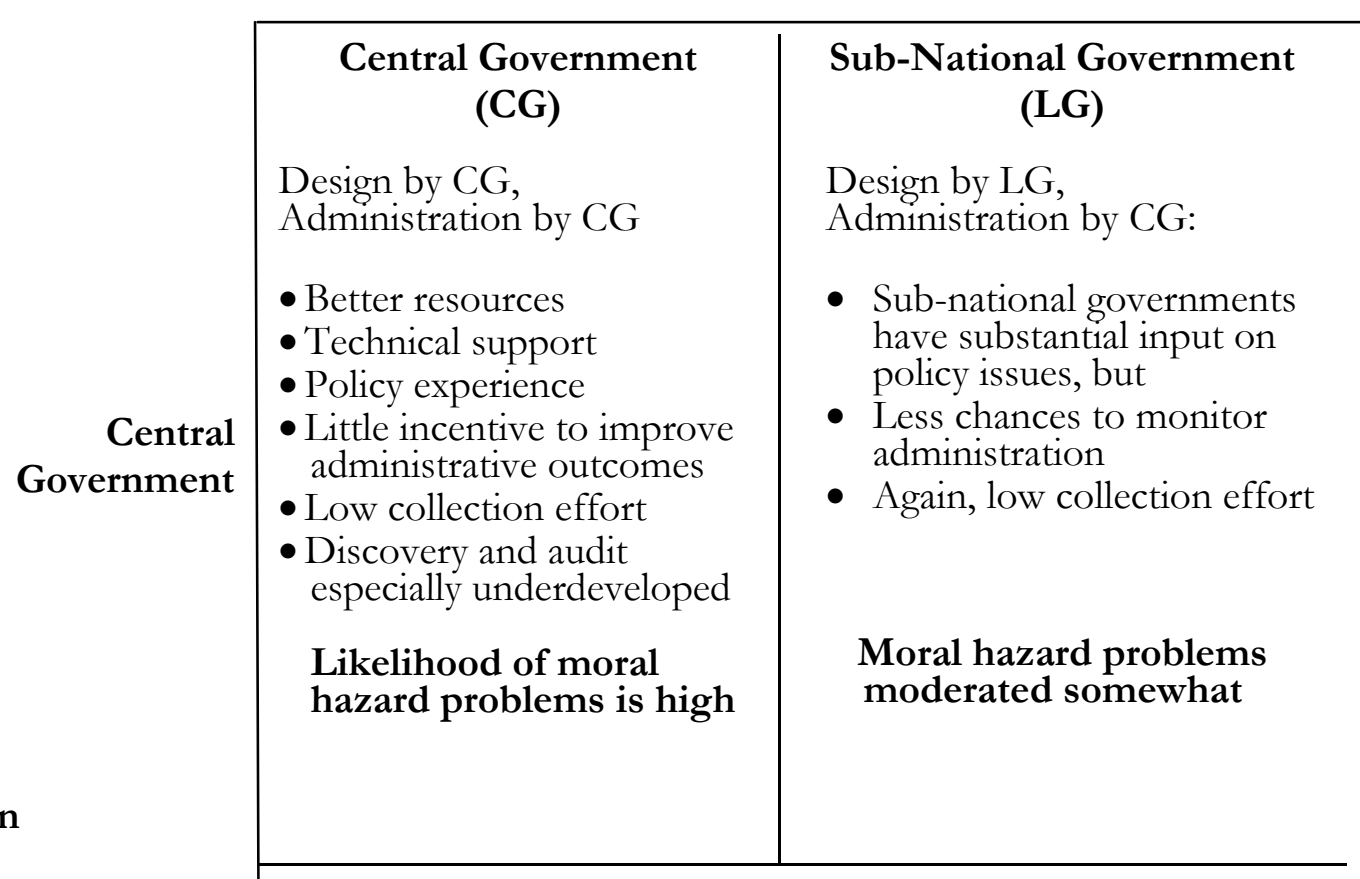




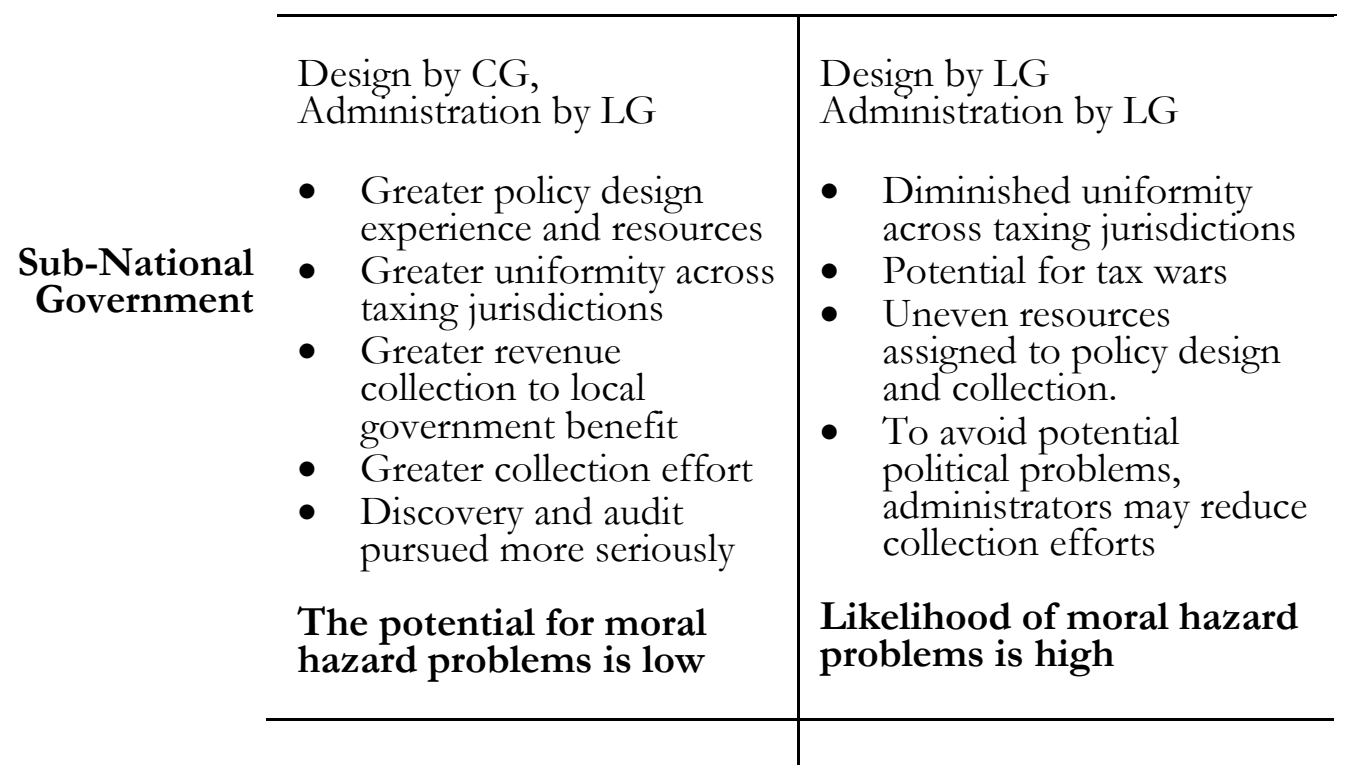

Table 2

Assorted Revenue and Budget Items, 1993 to 2000

(Billions of Crowns, Czech and Slovak)

\begin{tabular}{|c|c|c|c|c|c|c|c|c|c|c|}
\hline \multirow[b]{2}{*}{ Year } & \multicolumn{2}{|c|}{$\begin{array}{l}\text { GDP/Per } \\
\text { Capita SK and } \\
\text { CZ }\end{array}$} & \multicolumn{2}{|c|}{$\begin{array}{l}\text { National } \\
\text { Budget/Per } \\
\text { Capita SK and } \\
\text { CZ }\end{array}$} & \multicolumn{2}{|c|}{ Local Revenues } & \multicolumn{2}{|c|}{$\begin{array}{l}\text { National } \\
\text { Revenue } \\
\text { Sharing }\end{array}$} & \multicolumn{2}{|c|}{$\begin{array}{l}\text { Collected } \\
\text { Property Tax }\end{array}$} \\
\hline & Slovak & Czech & Slovak & Czech & Slovak & Czech & Slovak & Czech & Slovak & Czech \\
\hline 1993 & 73501 & 98764 & 42302 & 34654 & 13.2 & 91.1 & 1.50 & 27.0 & 1.60 & 3.01 \\
\hline 1994 & 85300 & 114423 & 38902 & 37644 & 14.2 & 112.0 & 1.10 & 31.0 & 2.03 & 3.85 \\
\hline 1995 & 101937 & 133678 & 45274 & 41468 & 15.7 & 113.0 & 1.20 & 34.8 & 2.05 & 3.82 \\
\hline 1996 & 112914 & 151899 & 47282 & 45000 & 19.5 & 163.8 & 1.30 & 61.5 & 2.88 & 4.02 \\
\hline 1997 & 127553 & 162942 & 49136 & 47339 & 20.1 & 145.3 & 1.80 & 35.9 & 3.14 & 3.94 \\
\hline
\end{tabular}




\begin{tabular}{|l|l|l|l|l|l|l|l|l|l|l|}
\hline 1998 & 139355 & 178437 & 50819 & 50325 & 18.9 & 157.2 & 2.08 & 37.4 & 3.21 & 4.11 \\
\hline 1999 & 151166 & 184994 & 58330 & 53194 & 17.8 & 165.6 & 2.24 & 41.4 & 3.76 & 4.25 \\
\hline 2000 & 164337 & 193205 & 60089 & 55339 & 20.1 & 181.8 & 2.77 & 46.1 & 3.61 & 4.45 \\
\hline 2001 & 179311 & 211441 & 61418 & 71222 & 23.0 & 192.4 & 3.88 & 67.3 & 3.69 & 4.60 \\
\hline
\end{tabular}

Source: Ministry of Finance, Czech Republic and Ministry of Finance, Slovak Republics, Statistical Yearbooks and our own calculations.

"National Revenue Sharing" refers to transfers of centrally-collected tax revenues from the state budget to the local budgets. Property tax, centrally collected in the Czech (but not Slovak) Republic, is obviously not included in this category. Other taxes earmarked for local governments and collected by the central government are included. This category does not include grants from the state budget, which are always for specific, state-approved purposes.

Table 2, Part 2

National and Local Budget Ratios

\begin{tabular}{|l|l|l|l|l|l|l|}
\hline & \multicolumn{2}{|l|}{ Natl Budget/GDP } & \multicolumn{2}{l|}{$\begin{array}{l}\text { Rev Sharing/Local } \\
\text { Revenues }\end{array}$} & \multicolumn{2}{l|}{$\begin{array}{l}\text { Property Tax/Local } \\
\text { Revenues }\end{array}$} \\
\hline Year & Slovak & Czech & Slovak & Czech & Slovak & Czech \\
\hline 1993 & 0.58 & 0.35 & 0.11 & 0.30 & 0.12 & 0.03 \\
1994 & 0.45 & 0.33 & 0.08 & 0.28 & 0.14 & 0.03 \\
1995 & 0.44 & 0.31 & 0.08 & 0.27 & 0.13 & 0.03 \\
1996 & 0.42 & 0.30 & 0.07 & 0.38 & 0.15 & 0.02 \\
1997 & 0.39 & 0.29 & 0.09 & 0.25 & 0.16 & 0.03 \\
1998 & 0.36 & 0.28 & 0.11 & 0.24 & 0.17 & 0.03 \\
1999 & 0.39 & 0.29 & 0.13 & 0.25 & 0.19 & 0.03
\end{tabular}




\begin{tabular}{|l|l|l|l|l|l|l|}
2000 & 0.37 & 0.29 & 0.14 & 0.25 & 0.18 & 0.02 \\
2001 & 0.34 & 0.34 & 0.17 & 0.35 & 0.16 & 0.02 \\
\hline
\end{tabular}

Same source. 